KEYWORDS

Fiscal policy

Gross domestic product

Investments

Monetary policy

Public debt

Interest rates

Mathematical models

Brazil
CEPAL REVIEW 103 A PRIL 2011

\section{Brazil: an empirical study on fiscal policy transmission}

\author{
Tito Belchior Silva Moreira
}

$\mathrm{T}$

his article sets out to empirically determine whether the ratio between debt and gross domestic product (GDP) affected real and nominal variables such as the demand for money, the nominal interest rate, investment and the output gap, between January 1995 and March 2008. The specific aim is to identify fiscal-policy transmission channels and decide whether this policy was active or passive in the period in question. The study finds empirical evidence that fiscal policy was active and monetary policy passive -features that characterize a non-Ricardian model.

\section{Tito Belchior Silva Moreira}

Professor and Research Fellow in the Department of Economics, Catholic University of Brasilia •ttito@pos.ucb.br 


\section{I}

\section{Introduction}

Given the nominal deficits recorded in recent decades, since 1999 the Brazilian authorities have adopted an inflation-targeting regime in a context of fiscal imbalance. Despite the successive primary surpluses achieved in recent years and relative stability in the debt/GDP ratio, the country's fiscal situation remains worrying, particularly in view of the rising trend of the debt/GDP ratio since the recent global financial crisis (subprime mortgage crisis). In 2009, federal tax revenue fell by $3.05 \%$ in real terms, while GDP declined by $0.2 \%$. At the same time, the Union's expenses increased by $12.51 \%$ on the 2008 figure, and its net debt grew from $23.44 \%$ of GDP in 2008 to $28.88 \%$ in $2009 .^{1}$

The high interest rates maintained by the Central Bank of Brazil to achieve its inflation targets contributed to the fact that debt service exceeded the primary surplus. Despite the drop in the Special Settlement and Custody System (SELIC) rate in 2009, Brazil still has one of the highest real interest rates in the world. Constant growth of the nominal deficit and, consequently, public debt, compounded by large short-term liabilities and high interest rates, make the fiscal deficit very worrying. ${ }^{2}$

The argument that Brazilian fiscal policy affects monetary policy to some extent seems to have foundation and is supported by some economists. It therefore seems sensible to consider fiscal variables when formulating an optimal monetary policy model for the central bank.

Nonetheless, using fiscal variables in the optimal monetary policy rule would mean admitting that the fiscal policy implemented in the Brazilian economy constrains the results and scope of monetary policy, thereby rendering it relatively or wholly ineffective. Assuming that the Central Bank of Brazil has to take account of the fiscal constraint in its monetary policy rule, implies admitting that monetary policy is not active or that fiscal policy is not passive, or both.

Generally speaking, optimal monetary policy models take fiscal policy as given and independent of

\footnotetext{
1 Data obtained from the government accounts audit for fiscal 2009 performed by the Federal Audit Department (Tribunal de Contas da União).

2 Souza, Moreira and Albuquerque (2007) analyse the long-term solvency of Brazil's public debt from January 1995 to July 2004, and show that this is not solvent unless seignorage is included as a source of income.
}

current and future monetary policy. This means that the fiscal policy authority chooses a tax rate to ensure that public debt is inter-temporally solvent. ${ }^{3}$ The Ricardian equivalence hypothesis is valid and, in that framework, monetary policy is active and fiscal policy passive. In situations of fiscal dominance, monetary policy will be passive and fiscal policy active.

According to Leeper (1991), the distinction between active and passive policy is based on the fact that the former takes into consideration not only the prior or current behaviour of certain variables (passive policy), but also the expected behaviour of certain variables in a given future period. An active policy is not constrained by current conditions, but makes it possible to formulate a decision rule that depends on past, current and future variables. A passive fiscal or monetary policy or authority is constrained by consumer optimizing conditions and the actions of the active authority. For example, if fiscal policy is passive, the fiscal authority's decision rule will necessarily depend on prior or current public debt.

Blanchard (2004) argues that discussion of the dominance of fiscal over monetary policy is not new, but spans from the modern literature of Sargent and Wallace (1981), as exemplified by "Some unpleasant monetarist arithmetic", to the fiscal theory of the price level (FTPL) propounded by Woodford (2003). ${ }^{4}$ In that regard, there has been renewed interest in the discussion on coordination and interaction between monetary and fiscal policies.

The main point of the FTPL line of research is that the present value of the government's budget constraint and fiscal policy are key factors in determining the price level. ${ }^{5}$

That argument stands in contrast to the traditional theory of price determination, in which the money supply, and hence the monetary authority, is the only factor determining the price level. Moreover, fiscal policy, either explicitly or implicitly, adjusts the primary

\footnotetext{
3 This broadly means that fiscal policy is passive.

4 See the papers by Loyo (1999) on an application of Woodford's theory to the case of Brazil, and Sala (2004) on the fiscal theory of the price level.

5 This regime is referred to by Woodford (1995) as "non-Ricardian price determination".
} 
surplus passively to guarantee the government's solvency irrespective of the price level.

The main purpose of this article is to use nonRicardian models to empirically determine whether fiscal policies had effects on real and nominal variables such as the demand for money, the nominal interest rate, investment and the output gap in the period running from January 1995 to March 2008. Its specific purpose is to evaluate the effects of the debt/GDP ratio on all of the variables mentioned, identify the channels through which fiscal policy is transmitted and decide whether fiscal policy was active or passive in the period analysed.

\section{II}

\section{Methodological issues}

The variables and the respective nomenclature used in this article (in parentheses) are as follows: Means of payment $(M)$; Nominal GDP $(Y)$; Nominal interest rate percentage $(R)$; Investment or gross fixed capital formation $(I)$; Implicit GDP deflator $(P)$; Nominal exchange rate $(E)$; Real effective exchange rate $(e)$; Primary surplus $(S P)$; Inflation rate $(\pi)$. The Federal government's direct income, in other words direct taxes $(D T)$, is obtained from the sum of personal and corporate income taxes and the rural property tax. Federal public bonds and open-market operations $(B)$ were used as a proxy for the public debt. A dummy variable was also used to distinguish the period of managed exchange rates (January 1995 to April 1998) from the "flexible" exchange-rate regime in the following period. Annex table A. 8 gives details of the variables used and specifies the sources and units of measurement.

Real GDP was calculated on the basis of the implicit GDP deflator. To calculate the output gap (y) the HodrickPrescott filter was used, which is defined as the difference between real GDP and potential GDP (trend). A positive value indicates excess demand. The extended national consumer price index (IPCA) ${ }^{6}$ was used to calculate the real interest rate $(r)$. In all the estimations, the variables were expressed as logarithms.

The time-series models are estimated in detail in section III. Johansen co-integration7 and unit root tests were used in addition to simultaneous equation models - the generalized method of moments with instrumental variables. An analysis was made of the

6 The real interest rate was calculated in the traditional way: $\left(1+R_{t}\right)$ $=\left(1+r_{t}\right) *\left[1+E_{t}\left(\pi_{t+1}\right)\right]$, assuming that $E_{t}\left(\pi_{t+1}\right)=\pi_{t+1}$.

7 The optimal number of lags was chosen on the basis of the following criteria: Modified sequential likelihood ratio test (LR); long-term equations arising from the co-integration tests, particularly to establish whether the public debt is significant and whether it has the expected sign in accordance with the theoretical model as presented. Other standard time-series techniques, such as weak exogeneity tests, were also used.

It should be noted that use of the generalized method of moments is appropriate when the regressors and error term are correlated, in which case instrumental variables should be used which are not correlated with the residuals, but are correlated with the regressors. The need to add instruments to estimate the coefficients creates an "over-identification" problem; and the J-statistic test was used to verify the existence of that problem. The null hypothesis is that the over-identification constraints are satisfied. The instruments are also used to resolve endogeneity problems.

When the variables are not stationary specific problems are known to arise in conventional inference procedures based on ordinary least squares (OLS) regressions. Johnston and DiNardo (1997, p. 317) stress the importance of knowing whether similar problems occur in the context of two-stage oLs regressions when faced with those difficulties. Hsiao (1997a and 1997b) analyse that problem and conclude that inference with two-stage least squares estimators using instrumental variables remains valid, even in the case of non-stationary or non-co-integrated series. In that context, Hsiao's conclusions also hold when the generalized method of moments is applied.
Final prediction error (EFP); Akaike information criterion (AIC); Schwarz information criterion; Hannan-Quinn information criterion (HQ). In cases where these indicators selected different lags, the most moderate model was chosen, in other words the model that indicated the smallest number of lags. 


\section{III}

\section{Presentation of non-Ricardian models and their results}

This section presents empirical data from fiscal sustainability tests and estimations of various theoretical models that relate the effect of certain fiscal variables on nominal and real variables in the economy. The following subsection considers the effect of the public debt on the demand for money.

\section{Effects of the public debt on the demand for money}

Kneebone (1989) defines the real demand for money as a negative function of the nominal interest rate and a positive function of output and real wealth. ${ }^{8}$ Net real wealth is defined as:

$$
W=M / P+\beta(B / P)]
$$

where $W$ is the net real wealth of private agents; $\beta$ is the fraction of government bonds that private agents perceive as net wealth $(0 \leq \beta \leq 1)$ and $B$ is the nominal value of government bonds outstanding. Moreover, if $Y / P$ represents real output, $R$ is the nominal interest rate; $P$ is the price level, and $M$ is a nominal money supply, then the real demand for money is given by

$$
M / P=L_{1}\left(Y / P+L_{2} R+L_{3}[M / P+\beta(B / P)]\right.
$$

According to Kneebone (1989), normalizing equation (2), by Y/P gives

$$
m=L_{1}+L_{2} R+L_{3}(m-\beta b)
$$

where $L_{1}>0, L_{2}<0$ and $L_{3}>0 ; m=M / Y ; b=B / Y$.

Equation (3) can also be written as

$$
m=\left(L_{1} / 1-L_{3}\right)+\left(L_{2} / 1-L_{3}\right) R+\beta\left(L_{3} / 1-L_{3}\right) b
$$

\footnotetext{
8 Scarth (1996) works with a similar approach for the real demand for money in a non-Ricardian equivalence setting.
}

A stochastic equation is then defined from equation (4), such that

$$
m_{t}=\beta_{0}+\beta_{1} R_{t}+\beta_{2} b_{t}+\eta_{t}
$$

where $\beta_{0}=\left(L_{1} / 1-L_{3}\right) ; \beta_{1}=\left(L_{2} / 1-L_{3}\right)$ and $\beta_{2}=\left(L_{3} / 1-L_{3}\right)$. If $\beta_{2}$ is statistically equal to zero, then the hypothesis of Ricardian equivalence is imposed.

Table A. 1 in the annex shows that $\mathrm{m}, \mathrm{b}$, and $\mathrm{R}$ are not stationary. As can be seen in annex tables A.4 and A.5, the Johansen co-integration tests indicate a cointegration equation with a $5 \%$ significance level. The model as presented also used a dummy variable, as an exogenous variable in the vector autoregression model (VAR). ${ }^{9}$ The long-term equation states that

$$
\begin{gathered}
m_{t}=1.632-0.534 R_{t}+0.438 b_{t} \\
(0.125)(0.089)(0.162)
\end{gathered}
$$

The figures in parentheses represent the standard deviations of the respective estimated coefficients. The long-term equation shows that for every $1 \%$ increase in the debt/GDP ratio, there is an increase of $0.438 \%$ in the demand for money. There is a positive Pearson correlation of $94.2 \%$ between those two variables at a $1 \%$ significance level. Based on the Chi-squared distribution, which has a value of 3.869, the null hypothesis of weak endogeneity of the debt/GDP ratio is rejected (probability value $=0.049$ ).

As expected, there is a negative relation between the interest rate and the demand for money. Every $1 \%$ increase in the SELIC rate generates a $0.534 \%$ reduction in the demand for money.

\section{- Fiscal sustainability test and effects of the public} debt on the demand for money

Luporini (2006) provides a good review and analysis of the various ways of testing fiscal sustainability that have been published in the literature. The present paper

\footnotetext{
9 On the basis of the Schwarz criterion (SIC), four lags were chosen.
} 
specifically uses the Buiter and Patel (1992) approach, which is also described by Luporini (2006).

Based on the article by Wilcox (1989), Buiter and Patel (1992) propose a robust solvency criterion which, in addition to the stationary nature of the debt, assumes that the latter cannot display a positive, stochastic, or deterministic trend. The test consists of estimating the following equation

$$
B_{t}=\alpha_{0}+\alpha_{1} \text { trend }+\sum_{i=1}^{\infty} \beta_{i} B_{t-i}+\varepsilon_{t}
$$

where $B$ is the public debt, trend is the trend term, and $\varepsilon$ is the stochastic term. According to Buiter and Patel (1992), insolvency can occur if at least one of the following conditions is fulfilled:

(i) The roots of $1-\beta(L)$ are not all outside the unit circle, in other words, the differential equation is not stable;

(ii) There is a deterministic trend, such that $\alpha_{1} \neq 0$ and the coefficient may be positive;

(iii) The expected mean is not zero, in other words, $\alpha_{0} \neq 0$, so the process governing the debt may be stationary, but its expected mean is not zero.

Also according to Buiter and Patel (1992), where

$$
B_{t}=\alpha_{0}+\alpha_{1} \text { trend }+\beta B_{t-1}+\varepsilon_{t}
$$

the null hypothesis of insolvency is given by $\beta_{1}=1$ and $\alpha_{1}=0$. In this context, it can be seen that:

(i) If the null hypothesis is not rejected, the discounted debt is not stationary, fiscal policy is unsustainable, and, if the situation persists indefinitely, insolvency will result;

(ii) If the null hypothesis is rejected but there is a positive deterministic trend, fiscal policy is relatively unsustainable because the insolvency problem will eventually arise;

(iii) If the null hypothesis is rejected and it is not possible to reject $\beta_{1}<1$ and $\alpha_{1}=0$, if there is a positive means such that $\alpha_{0}>0$, the situation once again will eventually lead to insolvency.

Buiter and Patel (1992) extend (generalize) the Wilcox (1989) statistical model, using techniques developed by Phillips and Perron (1988). Those authors show that $\alpha_{0}<0$ and $\alpha_{0}=0$ are conditions that are consistent with the situations of solid solvency and solvency, respectively. Consequently, if $\alpha_{0}>0$, the value of the discounted debt is positive. In that context, conditions for repaying the present value of the debt out of current and future primary surplus, or current and future seignorage, do not exist.
Equation (8) can be normalized through output, such that

$$
b_{t}=\alpha_{0}+\alpha_{1} \text { trend }+\beta b_{t-1}+\alpha_{2} d u m m y+\varepsilon_{t}
$$

where the dummy variable is introduced. It is thus possible to estimate equations (9) and (5) as a system using the generalized method of moments.

The results shown in table 1 indicate that all variables, except the constant and trend terms, are statistically significant at the $1 \%$ level. Based on the Wald test, the null hypothesis is not rejected, where the null hypothesis (Ho) is expressed as: $\beta_{1}=1$ and $\alpha_{1}=0$, the value of the Chi-squared distribution is 1.4286 and the $\mathrm{P}$ value is 0.4895 . In that context, as the null hypothesis is not rejected, fiscal policy is unsustainable, and if the situation persists indefinitely it will lead to insolvency.

The generalized method of moments with the Bartlett kernel, applied in conjunction with the two equations taken as a system, produces the statistics shown in tables 1 and 2 . The model specification is tested through the J-statistic linked to over-identification constraints. The J-statistic of 0.27 , together with a $\mathrm{P}$ value of 0.975 , do not provide evidence to reject the model specification.

TABLE 1

$$
\begin{aligned}
& \text { Estimation using the generalized method } \\
& \text { of moments with the Bartlett kernel, fixed } \\
& \text { bandwidth } \\
& \left(b_{t}=\alpha_{0}+\alpha_{1} \text { trend }+\beta b_{t-1}+\alpha_{2} \text { dummy }+\varepsilon_{t}\right)
\end{aligned}
$$

\begin{tabular}{lcccr}
\hline Variables & Coefficients & $\begin{array}{c}\text { Standard } \\
\text { deviation }\end{array}$ & $\begin{array}{c}\text { Student } \\
\text { t-statistic }\end{array}$ & P value \\
\hline Constant & $1.62 * 10^{-6}$ & 0.0079 & 0.0002 & 0.9998 \\
Trend & -0.0002 & 0.0003 & -0.6881 & 0.4931 \\
Debt/GDP(-1) & 1.0269 & 0.0243 & 42.3339 & $<0.0001$ \\
Dummy & 0.0719 & 0.0107 & 6.6889 & $<0.0001$ \\
$\mathrm{R}^{2}$ & 0.9769 & & Adjusted $\mathrm{R}^{2}$ & 0.9754 \\
\hline
\end{tabular}

Source: prepared by the author.

Note: Instruments $b(-3,-4,-5,-6), m(-3,-4,-5,-6), R(-3,-4,-5,-6)$, constant.

GDP: Gross domestic product

Trend: Trend

Dummy: Dummy variable

$P$ value: Probability

The results shown in table 2 indicate that all variables are statistically significant at the $1 \%$ level. The coefficients have the expected signs, such that for every $1 \%$ rise in the interest rate there is a $0.033 \%$ reduction in demand for money; and for every $1 \%$ increase in the 
TABLE 2

Estimation using the generalized method of moments with the Bartlett kernel, fixed bandwidth

$\left(m_{t}=\beta_{0}+\beta_{1} R_{t}+\beta_{2} b_{t} \eta_{t}\right)$

\begin{tabular}{lcccc}
\hline Variables & Coefficients & $\begin{array}{c}\text { Standard } \\
\text { deviation }\end{array}$ & $\begin{array}{c}\text { Student } \\
\text { t-Statistic }\end{array}$ & P value \\
\hline Constant & 0.1637 & 0.0027 & 60.9467 & $<0.001$ \\
SELIC & -0.0335 & 0.0041 & -8.1930 & $<0.001$ \\
Debt/GDP & 0.0818 & 0.0030 & 27.0272 & $<0.001$ \\
$\mathrm{R}^{2}$ & 0.8616 & & Adjusted $\mathrm{R}^{2}$ & 0.8556 \\
\hline
\end{tabular}

Source: prepared by the author.

Note: Instruments $b(-3,-4,-5,-6), m(-3,-4,-5,-6), R(-3,-4,-5,-6)$, constant.

GDP: Gross domestic product

SELIC: Special settlement and custody system rate

$P$ value: Probability

$\mathrm{debt} / \mathrm{GDP}$ ratio, there is a $0.082 \%$ increase in the demand for money. This shows that economic agents view part of the public debt as net wealth, so the model is nonRicardian. These results agree with those of equation (6) in terms of the significance and signs of the estimated coefficients.

The result shown in tables 1 and 2 are consistent and provide empirical evidence that, in the period analysed, Brazil had an unsustainable fiscal policy corresponding to a non-Ricardian model.

\section{Effects of the public debt on the primary surplus}

Bohn (1998) attempts to evaluate the sustainability of fiscal policy based on the response of the primary surplus to changes in the debt/GDP ratio. This relation is simplified through a regression of a following type:

$$
\begin{gathered}
\mathrm{SP} / \mathrm{Y}=0.004+0.031 * \mathrm{~B} / \mathrm{Y} \\
(0.002)(0.003)
\end{gathered}
$$

Table A.1 of the annex shows that both variables are first-order integrated I(1), and table A.2 shows cointegration at a 5\% significance level. The figures in parentheses represent the standard deviations of the respective estimated coefficients. The long-term equation shows that for every $1 \%$ increase in the debt/GDP ratio there is a $0.031 \%$ increase in the primary surplus/GDP ratio. ${ }^{10}$ The positive Pearson correlation between the two variables is $74.7 \%$ at the $5 \%$ significance level. It should also be noted that, based on the Chi-squared distribution, which has a value of 1.168 , the null hypothesis of weak endogeneity (probability $=0.279$ ) is not rejected; in other words, the debt/GDP ratio is weakly exogenous.

\section{- Fiscal sustainability test and the effects of the public debt on the primary surplus}

The results shown in table 3 indicate that all variables, except for the constant and trend terms, are statistically significant at the $1 \%$ level. In that context, as the null hypothesis is not rejected, fiscal policy is unsustainable, and if the situation persists indefinitely it will lead to insolvency.

The J-statistic of 0.274 , together with a $\mathrm{P}$ value of 0.90 , do not provide evidence to reject the model specification.

TABLE 3

$$
\begin{aligned}
& \text { Estimation using the generalized method } \\
& \text { of moments with the Bartlett kernel, fixed } \\
& \text { bandwidth }
\end{aligned}
$$

$$
\left(b_{t}=\alpha_{0}+\alpha_{1} \text { trend }+\beta b_{t-1}+\alpha_{2} \text { dummy }+\varepsilon_{t}\right)
$$

\begin{tabular}{lcccr}
\hline Variables & Coefficients & $\begin{array}{c}\text { Standard } \\
\text { deviation }\end{array}$ & $\begin{array}{c}\text { Student } \\
\text { t- Statistic }\end{array}$ & P value \\
\hline Constant & 0.0009 & 0.0086 & 0.1105 & 0.9122 \\
Trend & $-2.80 * 10^{-5}$ & 0.0003 & -0.0799 & 0.9365 \\
Debt/GDP(-1) & 1.0123 & 0.0201 & 50.3442 & $<0.0001$ \\
Dummy & 0.0691 & 0.0086 & 8.0382 & $<0.0001$ \\
$\mathrm{R}^{2}$ & 0.9815 & & Adjusted $\mathrm{R}^{2}$ & 0.9803 \\
\hline
\end{tabular}

Source: prepared by the author.

Note: Instruments $b(-2,-3,-4,-5,-6), s p(-2,-3,-4,-5,-6), R(-2,-3,-4$, $-5,-6)$, constant.

GDP: Gross domestic product

Trend: Trend

Dummy: Dummy variable

$P$ value: Probability

The results shown in table 4 indicate that all variables are statistically significant at the $1 \%$ level. The coefficients have the expected signs, such that for every $1 \%$ increase

\footnotetext{
10 Based on the Schwarz (SIC) and Hannan-Quinn (HQ) information criteria, one lag was chosen.
} 
in the debt/GDP ratio, there is a $0.03 \%$ increase in the primary surplus/GDP ratio, which means that the primary surplus reacts to variations in the public debt.

TABLE 4

Estimation using the generalized method of moments with the Bartlett kernel, fixed bandwidth

$\left(s p_{t}=\beta_{0}+\beta_{1} b_{t}+\eta_{t}\right)$

\begin{tabular}{lcccr}
\hline Variables & Coefficients & $\begin{array}{c}\text { Standard } \\
\text { deviation }\end{array}$ & $\begin{array}{c}\text { Student } \\
\text { t-Statistic }\end{array}$ & P value \\
\hline Constant & 0.0049 & 0.0006 & 7.6443 & $<0.0001$ \\
Debt/GDP & 0.0305 & 0.0014 & 21.7183 & $<0.0001$ \\
$\mathrm{R}^{2}$ & 0.6151 & & Adjusted R & 0.6070 \\
\hline
\end{tabular}

Source: prepared by the author.

Note: Instruments $b(-2,-3,-4,-5,-6), s p(-2,-3,-4,-5,-6), R(-2,-3,-4$, $-5,-6)$, constant.

GDP: Gross domestic product

$P$ value: Probability

\section{Brief remarks on the relation between the primary surplus, the single national treasury account, and the monetary base}

It is worth noting that the federal government's primary surplus is recorded in the single account of the National Treasury, which in turn forms part of the nonmonetary liability of the central bank. As the variation in the monetary base corresponds to the difference between the variation in central bank's assets and the variation in its nonmonetary liabilities, an increase in the primary surplus (and hence in the National Treasury single account recorded in the non-monetary liability), with everything else held constant, means the monetary base will shrink. In that context, successive increases in the primary surplus will lead to a contraction in the monetary base ceteris paribus, and consequently a reduction in means of payment. This institutional structure reveals the existence of a direct transmission channel from fiscal policy to monetary policy. In conjunction with this, if the public debt which responds to variations in the primary surplus positively affects the demand for money, both the public debt and the primary surplus can be expected to have repercussions on the interest rate. But, in which direction?

If the interest rate is determined by the supply and demand for money, and if the latter responds positively to variations in the public debt, for a given money supply, the interest rate will rise. Secondly, knowing that increases in the primary surplus cause a reduction in the monetary base, once again ceteris paribus, the interest rate will rise. Although it is well known that the money supply is endogenous in an inflation-targeting regime (because the central bank Brazil controls the SELIC rate), this is merely an intuitive exercise to evaluate the direction of interest-rate movements in response to an increase in the public debt.

\section{Effects of the public debt on the interest rate}

- Fiscal sustainability test and effects of the public debt on the interest rate

Martins (1980) develops a theory of the determination of nominal income and the interest rate based on the hypothesis that economic agents can, at different times, hold government bonds and money in their portfolio. Agents take account of the government's budget constraint, and are not concerned about the future discount rate on liabilities stemming from the issuance of government bonds. Under that theory, the price of bonds is analogous to the price level. Moreover, the nominal interest rate is determined by the relation between the amounts of government bonds and money, and has no relation with the rate of increase in the price level. That result assumes that the Fisher theory (Fisher, 1930, chapters. 2 and 19) on the nominal interest rate is not maintained. Moreira and Souza (2009) test the Martins (1980) model and, on the basis of panel data for the period 1980-2006, show that the ratio between the public debt and the monetary aggregate M1 affects the nominal interest rate.

In keeping with the Martins (1980) model, the fundamental equation can be written as $R_{t}=B_{t} / M_{t}$, where $R_{t}=\left(1+i_{t}\right), t$ represents time, $i$ represents the nominal interest rate, $B$ is the amount of government bonds, and $M$ the money supply, measured as M1. Expressing both sides of the equation as logarithms, and representing it in stochastic form gives:

$$
\log \left(R_{t}\right)=\log \left(B_{t}\right)-\log \left(M 1_{t}\right)+e_{t}
$$

This section estimates two systems to evaluate the effects of the public debt on the interest rate (SELIC). The objective of the first consists of evaluating the direct effect according to data presented in tables 5 and 6 , whereas the aim of the second is to evaluate the indirect effect of the public debt on the interest rate through the primary surplus, as shown in tables 7,8 , and 9 . The direct effect of the primary surplus on the interest rate is thus also tested. 
TABLE 5

Estimation using the generalized method of moments with the Bartlett kernel, fixed bandwidth

$\left(B_{t}=\alpha_{0}+\alpha_{1}\right.$ trend $+\beta B_{t-1}+\alpha_{2}$ dummy $\left.+\varepsilon_{t}\right)$

\begin{tabular}{lcccr}
\hline Variables & Coefficients & $\begin{array}{c}\text { Standard } \\
\text { deviation }\end{array}$ & $\begin{array}{c}\text { Student } \\
\text { t-Statistic }\end{array}$ & P value \\
\hline Constant & 1.9346 & 0.6172 & 3.1344 & 0.0023 \\
Trend & 0.0033 & 0.0019 & 1.7091 & 0.0908 \\
Debt (-1) & 0.8522 & 0.0499 & 17.0591 & $<0.0001$ \\
Dummy & -0.1051 & 0.0409 & -2.5648 & 0.0120 \\
$\mathrm{R}^{2}$ & 0.9957 & & Adjusted $\mathrm{R}^{2}$ & 0.9954 \\
\hline
\end{tabular}

Source: prepared by the author.

Note: Instruments $B(-2,-3,-4,-5,-6), R(-2,-3,-4,-5,-6)$, constant.

Trend: Trend

Dummy: Dummy variable

$P$ value: Probability

TABLE 6

Estimation using the generalized method of moments with the Bartlett kernel, fixed bandwidth

$\left(R_{t}=\beta_{0}+\beta_{1} B_{t}+\beta_{2} M 1_{t} \eta_{t}\right)$

\begin{tabular}{lcccr}
\hline Variables & Coefficients & $\begin{array}{c}\text { Standard } \\
\text { deviation }\end{array}$ & $\begin{array}{c}\text { Student } \\
\text { t-Statistic }\end{array}$ & P value \\
\hline Constant & 0.0553 & 0.0097 & 5.6843 & $<0.0001$ \\
Debt & 0.0245 & 0.0067 & 3.6683 & 0.0004 \\
M1 & 0.0325 & 0.0073 & 4.4298 & $<0.0001$ \\
$\mathrm{R}^{2}$ & 0.1225 & & Adjusted $\mathrm{R}^{2}$ & 0.0843 \\
\hline
\end{tabular}

Source: prepared by the author.

Note: Instruments $B(-2,-3,-4,-5,-6), R(-2,-3,-4,-5,-6)$, constant.

M1: Means of payment

$P$ value: Probability

The results shown in table 5 indicate that all variables, except the trend term, are statistically significant at the 5\% level. In that situation, as the null hypothesis is rejected but there is a positive deterministic trend, fiscal policy is relatively unsustainable, and the insolvency problem will eventually arise.

The J-statistic of 0.22 and a $P$ value of 0.99 do not provide evidence to reject the model specification.

The results shown in table 6 indicate that all variables are statistically significant at the $1 \%$ level. The coefficient on the public debt shows that for every $1 \%$ increase in the debt the interest rate rises by $0.02 \%$. This means that government debt has a positive and significant effect on the interest rate, suggesting a non-Ricardian model and an active fiscal policy. It also shows that when the government increases liquidity in
TABLE 7

Estimation using the generalized method of moments with the Bartlett kernel, fixed bandwidth

$\left(B_{t}=\alpha_{0}+\alpha_{1}\right.$ trend $+\beta B_{t-1}+\alpha_{2}$ dummy $\left.+\varepsilon_{t}\right)$

\begin{tabular}{lcccr}
\hline Variables & Coefficients & $\begin{array}{c}\text { Standard } \\
\text { deviation }\end{array}$ & $\begin{array}{c}\text { Student } \\
\text { t-Statistic }\end{array}$ & P value \\
\hline Constant & 1.7303 & 0.1425 & 12.1408 & $<0.0001$ \\
Trend & 0.0025 & 0.0004 & 6.1506 & $<0.0001$ \\
Debt (-1) & 0.8691 & 0.0115 & 75.2616 & $<0.0001$ \\
Dummy & -0.1086 & 0.0048 & -22.4522 & $<0.0001$ \\
$\mathrm{R}^{2}$ & 0.9955 & & Adjusted $\mathrm{R}^{2}$ & 0.9952 \\
\hline
\end{tabular}

Source: prepared by the author.

Note: Instruments $B(-2,-3,-4,-5,-6), R(-2,-3,-4,-5,-6), S P(-2,-3,-4$, $-5,-6)$, constant.

Trend: Trend

Dummy: Dummy variable

$P$ value: Probability

TABLE 8

Estimation using the generalized method of moments with the Bartlett kernel, fixed bandwidth

$\left(s p_{t}=\beta_{0}+\beta_{1} B_{t}+\eta_{t}\right)$

\begin{tabular}{lcccr}
\hline Variables & Coefficients & $\begin{array}{c}\text { Standard } \\
\text { deviation }\end{array}$ & $\begin{array}{c}\text { Student } \\
\text { t-Statistic }\end{array}$ & P value \\
\hline Constant & -2.1326 & 0.0656 & -32.4982 & $<0.0001$ \\
Debt & 0.8566 & 0.0048 & 177.7032 & $<0.0001$ \\
$\mathrm{R}^{2}$ & 0.6431 & & Adjusted $\mathrm{R}^{2}$ & 0.6355 \\
\hline
\end{tabular}

Source: prepared by the author.

Note: Instruments $B(-2,-3,-4,-5,-6), R(-2,-3,-4,-5,-6), S P(-2,-3,-4$, $-5,-6)$, constant.

$P$ value: Probability

TABLE 9

Estimation using the generalized method of moments with the Bartlett kernel, fixed bandwidth

$\left(R_{t}=\beta_{0}+\beta_{1} S P_{t}-\beta_{2} M 1_{t} \eta_{t}\right)$

\begin{tabular}{lcccr}
\hline Variables & Coefficients & $\begin{array}{c}\text { Standard } \\
\text { deviation }\end{array}$ & $\begin{array}{c}\text { Student } \\
\text { t-Statistic }\end{array}$ & P value \\
\hline Constant & 0.0778 & 0.0009 & 78.0522 & $<0.0001$ \\
SP & 0.0011 & 0.0001 & 6.8915 & $<0.0001$ \\
M1 & 0.0065 & 0.0002 & 32.9243 & $<0.0001$ \\
$\mathrm{R}^{2}$ & 0.5067 & & Adjusted R & 0.4852 \\
\hline
\end{tabular}

Source: prepared by the author.

Note: Instruments $B(-2,-3,-4,-5,-6), R(-2,-3,-4,-5,-6), S P(-2,-3,-4$, $-5,-6)$, constant.

SP: Primary surplus.

M1: Means of payment

$P$ value: Probability 
the economy, the interest rate falls. Every $1 \%$ increase in the monetary aggregate M1 produces a $0.03 \%$ drop in the nominal interest rate.

The results for the second system of equations are shown below, based on three equations, and according to the data shown in table 7,8 , and 9 . The results shown in table 7 indicate that all variables are statistically significant at the $1 \%$ level. In that context, as the null hypothesis is rejected but there is a positive deterministic trend, fiscal policy is relatively unsustainable, because the insolvency problem will eventually arise. The Wald test does not accept the null hypotheses that $\beta=1$, with a value $\mathrm{P}<0,0001$.

The value of the J-statistic at 0.20 , with a $\mathrm{P}$ value of 0.90 , does not provide evidence to reject the model specification.

The parameters shown in table 8 are statistically significant at the $1 \%$ level. Every $1 \%$ increase in the public debt produces a $0.85 \%$ increase in the primary surplus.

The results shown in table 9 indicate that all variables are statistically significant at the $1 \%$ level. Every $1 \%$ increase in the primary surplus produces a $0.001 \%$ increase in the nominal interest rate. This shows that the primary surplus has a positive and significant effect on the interest rate, suggesting an active fiscal policy and a passive monetary policy; in other words, a non-Ricardian model. It can also be seen that when the government increases liquidity in the economy, the interest rate falls. For every $1 \%$ increase in the monetary aggregate M1, the nominal interest rate drops by $0.006 \%$.

When analysing the repercussions of an increase in the public debt or the primary surplus on the interest rate, it is natural also to examine the effect of those fiscal variables on the level of investment in the economy. This relation is analysed below.

\section{Effect of the public debt on investment}

Araujo and Martins (1999) show that long-term sustainable growth is possible in a sector overlappinggenerations model. They assume a convex technology, no redistribution of income from the previous generation to later ones, with income taxation and without the pure altruism sustained by Barro (1974). Working with a production function of the type $Y=A K$, and assuming that the agent's utility function incorporates an absolute inheritance motive, the authors deduce a clear policy repercussion from the model: an increase in government debt has a negative effect on the rate of growth of the capital stock, such that

$$
\frac{K_{t}-K_{t-1}}{K_{t-1}}=\frac{\delta A-1}{1+\delta}-\frac{B_{t} / K_{t-1}}{(1+A)(1+\delta)}
$$

where $K_{t}$ is the capital stock at the start of period $t, B_{t}$ is the amount of government bonds at the start of $t, A$ represents technology and the coefficient $\delta$ indicates agents' preferences. Equation (12) shows that the rate of growth of the capital stock is endogenous. In that context, the flow of debt financing as a proportion of the capital stock in the previous period negatively affects the capital accumulation rate. This is due to a crowding-out effect in which productive investment is reduced as a result of an increase in public debt. ${ }^{11}$

As investment is the difference between the capital stock at times $t$ and $t-1$ (in other words $K_{t}-K_{t-1}=I_{t}$ ), and that $Y_{t-1}=A K_{t-1}$, equation (12) can be rewritten as follows:

$$
I_{t} / Y_{t-1}=\beta_{0}+\beta_{1} *\left(B_{t} / Y_{t-1}\right)
$$

where $\beta_{0}=(\delta A-1) / A(1+\delta)$ and $\beta_{1}=-1 /[(1+A)(1+\delta)]$. Having established this, the equation is estimated as follows:

$$
I_{t} / Y_{t-1}=\beta_{0}+\beta_{1} *\left(B_{t} / Y_{t-1}\right)+u_{t}
$$

where the parameter $\beta_{1}$ shows the relation between the ratios debt $(t) / \mathrm{GDP}(t-1)$ and investment $(t) /$ nominal GDP $(t-1), \beta_{0}$ is the intercept parameter, and $u_{t}$ is the (stochastic) error term. Next the parameter $\beta_{1}$ is evaluated for statistical significance (different from zero) and sign. If $\beta_{1}$ is negative and statistically significant, it can be inferred that the debt/GDP ratio negatively affects the investment $(\mathrm{t}) /$ nominal GDP $(\mathrm{t}-1)$ ratio. In other words, if $\beta_{1}=0$, Ricardian equivalence is imposed. Equation (14) can also be empirically tested with the following functional form: $I_{t}=\beta_{0}+\beta_{1} Y_{t-1}+\beta_{2} * B_{t}+u_{t}$.

Firstly, the aforementioned variables are tested for stationarity, and if no whether they co-integrate. Table A.1 of the annex shows that neither variable is stationary. The Johansen co-integration tests show that there is a

11 Mendonça, Medrano and Sachsida (2009) analyse the effects of fiscal crises on the Brazilian economy between January 1995 and December 2007. The results suggest that following an unexpected increase in government spending: (i) private consumption rises; (ii) GDP decreases (with a probability of $77.1 \%$ ); and (iii) the interest rate rises. This could indicate a crowding-out effect between public and private investment. 
co-integration equation at the 5\% significance level, according to the data shown in annex tables A.2 and A.3. ${ }^{12}$ The model presented here used a dummy variable (as an exogenous variable in the vector autoregression model - VAR $).{ }^{13}$

In the resulting long-term equation, the parameter $\beta_{1}$ is marginally significant (barely above $5 \%$ ) as shown below:

$$
\begin{gathered}
I_{t} / Y_{t-1}=-1.621-0.220\left(B_{t} / Y_{t-1}\right) \\
(0.073)(0.116)
\end{gathered}
$$

The figures in parentheses represent the standard deviations of the respective estimated coefficients. According to the long-term equation, for every $1 \%$ increase in the $\operatorname{debt}(t) / \mathrm{GDP}(t-1)$ ratio, there is a $0.22 \%$ reduction in the investment $(t) / \operatorname{GDP}(t-1)$ ratio. The negative Pearson correlation between the two variables is $-27.3 \%$ at the 5\% significance level. Moreover, based on the Chi-squared distribution, which shows a value of 1.819, the null hypothesis of weak endogeneity $(\mathrm{P}=0.177)$ is not rejected; in other words, the $\operatorname{debt}(t) / \mathrm{GDP}$ nominal $(t-1)$ ratio is weakly exogenous.

The public debt does not have a neutral role on the real variable of the economy - the ratio of investment to GDP. These empirical tests suggest a clear public policy prescription: the government should set a target for reducing the debt/GDP ratio. This would raise the investment/GDP ratio, leading to higher growth, less unemployment and, hence, an improvement in the population's living standards.

\section{- Fiscal sustainability test and effects of the public debt on gross fixed capital formation}

The results shown in table 10 indicate that all variables, except the trend term, are statistically significant at the $5 \%$ level. In that context, if the null hypothesis is not rejected, the discounted debt is not stationary, fiscal policy is unsustainable; and, if the situation persists indefinitely, it will result in insolvency. The Wald test does not reject the null hypothesis that $\beta_{1}=1$ and $\alpha_{1}=0$, with the Chi-squared distribution equal to 4.0573 and a $P$ value of 0.1315

\footnotetext{
12 Based on the SC (Schwarz information criterion) and LR (Likelihood information criterion), one lag was chosen.

13 In terms of the specification of the cointegration test, the most usual model was used which is best adapted to the data, namely, the model that includes the intercept in the cointegration equation and in the VAR, which does not include the trend. This model was used in long-term equations 6,10 , and 15 .
}

The value of the J-statistic at 0.274 , with a $\mathrm{P}$ value of 0.90 , does not provide evidence to reject the model specification.

TABLE 10

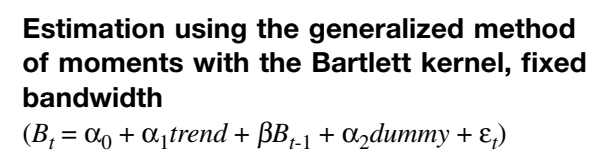

Estimation using the generalized method of moments with the Bartlett kernel, fixed bandwidth

$\left(B_{t}=\alpha_{0}+\alpha_{1}\right.$ trend $+\beta B_{t-1}+\alpha_{2}$ dummy $\left.+\varepsilon_{t}\right)$

\begin{tabular}{lcccr}
\hline Variables & Coefficients & $\begin{array}{c}\text { Standard } \\
\text { deviation }\end{array}$ & $\begin{array}{c}\text { Student } \\
\text { t-Statistic }\end{array}$ & P value \\
\hline Constant & 0.3812 & 0.1837 & 2.0750 & 0.0408 \\
Trend & 0.0016 & 0.0010 & 1.5888 & 0.1156 \\
Real debt (-1) & 0.9549 & 0.0246 & 38.8315 & $<0.0001$ \\
Dummy & 0.0378 & 0.0099 & 3.8098 & 0.0003 \\
$\mathrm{R}^{2}$ & 0.9968 & & Adjusted $\mathrm{R}^{2}$ & 0.9966 \\
\hline
\end{tabular}

Source: prepared by the author.

Note: Instruments $B(-2,-3,-4,-5,-6), I(-2,-3,-4,-5,-6), R(-2,-3,-4$, $-5,-6)$, constant.

Trend: Tendency

Dummy: Dummy variable

P value: Probability

TABLE 11

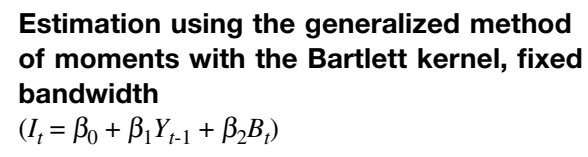

Estimation using the generalized method of moments with the Bartlett kernel, fixed bandwidth $\left(I_{t}=\beta_{0}+\beta_{1} Y_{t-1}+\beta_{2} B_{t}\right)$

\begin{tabular}{lcccr}
\hline Variables & Coefficients & $\begin{array}{c}\text { Standard } \\
\text { deviation }\end{array}$ & $\begin{array}{c}\text { Student } \\
\text { t-Statistic }\end{array}$ & P value \\
\hline Constant & -3.1073 & 0.1800 & -17.2566 & $<0.0001$ \\
Real GDP (-1) & 1.4357 & 0.0515 & 27.8792 & $<0.0001$ \\
Real debt & -0.2557 & 0.0301 & -8.4955 & $<0.0001$ \\
$\mathrm{R}^{2}$ & 0.9781 & & Adjusted $\mathrm{R}^{2}$ & 0.9772 \\
\hline
\end{tabular}

Source: prepared by the author.

Note: Instruments $B(-2,-3,-4,-5,-6), I(-2,-3,-4,-5,-6), R(-2,-3,-4$, $-5,-6)$, constant.

GDP: Gross domestic product

$P$ value: Probability

The results shown in table 11 indicate that all variables are statistically significant at the $1 \%$ level. For every $1 \%$ increase in real debt there is a $0.256 \%$ reduction in gross fixed capital formation. This shows that the debt has a negative and significant effect on investment, which suggests an active fiscal policy. There is also a positive effect on investment of lagged real GDP.

Given the negative effect of the public debt on the level of investment, it is natural to test its repercussions on output. The next subsection verifies the effect of the primary surplus and the public debt on the output gap. 


\section{Effects of the primary surplus and public debt on the output gap}

This subsection estimates the equations of the fiscal IS curve and the relation between the primary surplus and the public debt. Estimation of the equation that measures the response of the primary surplus as a proportion of GDP (SP/Y), to the levels of the public debt/GDP ratio $(\mathrm{B} / \mathrm{Y})$, can be defined as

$$
(S P / Y)_{t}=a_{0}+a_{1}(S P / Y)_{t-1}+a_{2}(B / Y)_{t-1}+u_{t}
$$

where $u_{t}$ is the stochastic term.

The fiscal IS curve can be defined as

$$
y_{t}=a_{3}+a_{4} y_{t-1}+a_{5} r_{t-1}+a_{6}(S P / Y)_{t-1}+a_{7} e_{t-1}+\eta_{t}
$$

where $y_{t}$ is the output gap, $r_{t}$ is the real interest rate, $(S P / Y)$ t is the fiscal variable interest (primary surplus/GDP), $e_{t}$ is the real exchange rate and $\eta_{t+1}$ is the stochastic term. The name "fiscal IS" reflects the fact that the IS curve includes a fiscal variable. It is possible for the stochastic terms of equations (16) and (17) not to be serially correlated.

This model can be used to verify the direct effects of the public debt on the primary surplus and the indirect effect of that variable (public debt) on the output gap. If the public debt/GDP ratio is statistically significant in equation (16), and the ratio between the primary surplus and GDP is also statistically significant in equation (17), then fiscal policy is active. This means that government debt indirectly affects a real variable, the output gap, through the primary surplus.

The results shown in table 12 indicate that all variables are statistically significant at the $1 \%$ level, and that for every $1 \%$ increase in the debt/GDP ratio, the primary surplus/GDP ratio increases by $0.023 \%$. These results are consistent with those of equation (10) in terms of the significance and signs of the estimated coefficients. Equation (16) differs from equation (10), because it has the lagged dependent variable as an explanatory variable, in this case the primary surplus/ GDP ratio, in $t-1$.

The value of the J-statistic at 0.28 , with a $\mathrm{P}$ value of 0.50 , does not provide evidence to reject the model specification.

The results shown in table 13 also indicate that all variables are statistically significant at the 5\% level. A $1 \%$ increase in the primary surplus/GDP ratio is associated with a $2.963 \%$ reduction in the output gap, such that the final effect of the $1 \%$ increase in the debt/GDP ratio will
TABLE 12

Estimation using the generalized method of moments with the Bartlett kernel, fixed bandwidth

$\left((S P / Y)_{t}=a_{0}+a_{1}(S P / Y)_{t-I}+a_{2}(B / Y)_{t-1}+u_{t}\right)$

\begin{tabular}{lcccr}
\hline Variables & Coefficients & $\begin{array}{c}\text { Standard } \\
\text { deviation }\end{array}$ & $\begin{array}{c}\text { Student } \\
\text { t-Statistic }\end{array}$ & P value \\
\hline Constant & 0.004 & $<0.001$ & 18.045 & $<0.001$ \\
(SP/Y) (-1) & 0.221 & 0.026 & 8.411 & $<0.001$ \\
{$[\mathrm{~B} / \mathrm{Y}](-1)$} & 0.023 & $<0.001$ & 27.670 & $<0.001$ \\
$\mathrm{R}^{2}$ & 0.612 & & Adjusted $\mathrm{R}^{2}$ & 0.595 \\
\hline
\end{tabular}

Source: prepared by the author.

Note: Instruments $y(-3,-4,-5,-6), r(-3,-4,-5,-6), S P / Y(-3,-4,-5,-6)$, $e(-3,-4,-5,-6), B / Y(-3,-4,-5,-6)$, c.

SP: Primary surplus

$P$ value: Probability

TABLE 13

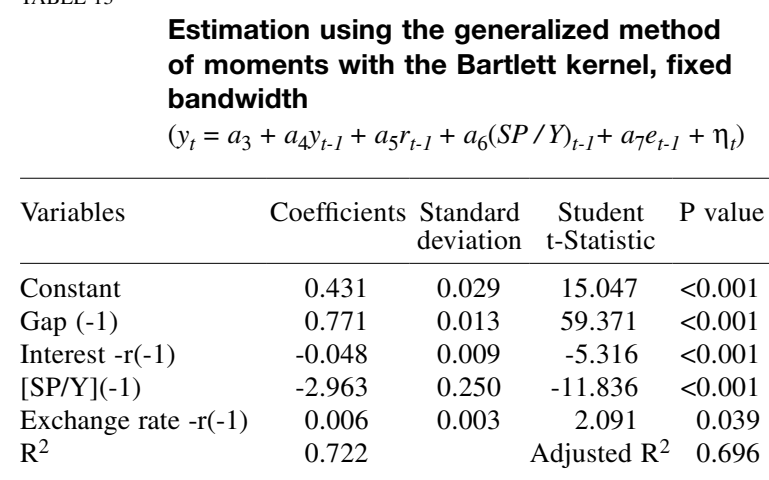

Source: prepared by the author.

Note: Instruments $y(-3,-4,-5,-6), r(-3,-4,-5,-6), S P / Y(-3,-4,-5,-6)$, $e(-3,-4,-5,-6), B / Y(-3,-4,-5,-6), \mathrm{c}$.

SP: Primary surplus.

$P$ value: Probability

be a reduction of $0.07 \%$ in the short-term output gap. In the long term, bearing in mind the autoregressive effect of the coefficient of the lagged output gap, the final effect will be a reduction in the output gap of $0.31 \%$. This result empirically proves that fiscal policy is active.

The other coefficients have the expected signs, such that for every $1 \%$ increase in the real interest rate there is a $0.048 \%$ reduction in the output; and for every $1 \%$ increase in the real exchange rate, the output gap grows by $0.006 \%$.

Although the primary surplus responds to variations in the public debt, which could reflect government concern for the budget constraint, nothing guarantees that this reaction is strong enough to make the debt solvent. If the magnitude of the reaction is appropriate, fiscal policy would be passive; in other words, there would be no effect on real variables, including the output gap. 
To ensure the robustness of the results, an alternative method was used to measure the output gap. In keeping with the work of Cusinato, Minella and Junior (2010) on measures of the output gap in Brazil, it was decided to use the method of extraction of quadratic trend, which is a natural extension of the linear trend, adding a quadratic term, such that $y_{t}=\alpha+\beta_{1} t+\beta_{2} t^{2}+e_{t}$, where $\mathrm{t}=1,2, \ldots . \mathrm{T}$. the results obtained are similar to those shown in tables 12 and 13, which use an output gap based on the Hodrick-Prescott (1997) filter.

To validate the empirical tests presented above, one further test was undertaken using the Leeper (1991) model, as described below.

\section{Fiscal dominance: Empirical tests based on the Leeper model}

The model formulated by Leeper in 1991 defined conditions under which monetary and fiscal policies can be classified as passive or active, where $B$ is the nominal government debt on which a nominal interest rate $\left(R_{t}\right)$ is paid, $\tau$ represents direct taxes as the overall sum (positive) and transfer (if negative), and $p$ is the price level. This gives $\pi_{t}=p_{t} / p_{t-1}$ and $b_{t}=B_{t} / p_{t}$.

The author describes government policies on the basis of simple rules, in which fiscal policy is given by

$$
\tau_{t}=\gamma_{0}+\gamma b_{t-1}+\Psi_{t}
$$

where $\Psi_{t}$ is the exogenous crisis occurring at the start of $t$, such that

$$
\Psi_{t}=\rho_{\Psi} \Psi_{t-1}+\varepsilon_{\Psi t}
$$

with $\left|\rho_{\Psi}\right|<1$ and $E_{t} \varepsilon_{\Psi t+1}=0$. Monetary policy also obeys a simple interest-rate rule as described by Taylor (1993), such that

$$
R_{t}=\alpha_{0}+\alpha \pi_{t}+\theta_{t}
$$

where $\theta_{t}$ is an exogenous crisis, occurring at the start of $t$, such that

$$
\theta_{t}=\rho_{0} \theta_{t-1}+\varepsilon_{\theta t}
$$

with $\left|\rho_{0}\right|<1$ and $E_{t} \varepsilon_{\theta t+1}=0$.

In solving the model, Leeper shows how equilibrium depends on the parameters $(\alpha, \gamma)$. The author shows that this non-linear model cannot be resolved analytically, and reduces it to a dynamic system, in $\left(\pi_{t}, b_{t}\right)$ to find two roots: $\alpha \beta$ and $\beta^{-1}-\gamma$, where $\beta$ is the time preference rate. In this context, the author shows that one of the roots must be greater than 1 and the other less than 1 in absolute terms. Consequently, four regions are generated, as follows:

Region I: $\quad|\alpha \beta| \geq 1$ and $\left|\beta^{-1}-\gamma\right|<1$

Unique equilibrium. Ricardian equivalence is maintained in this region. In this case, monetary policy is active and fiscal policy passive. This is the ideal region for an economy to implement a system of inflation targeting by controlling the interest rate.

Region II: $|\alpha \beta|<1$ and $\left|\beta^{-1}-\gamma\right| \geq 1$

Unique equilibrium. This region describes the fiscal theory of the price level or the situation known as fiscal dominance, in which fiscal policy is active and monetary policy is passive.

Region III: $|\alpha \beta|<1$ and $\left|\beta^{-1}-\gamma\right|<1$

In this region, the fiscal and monetary authorities act passively, subject to the budget constraint, so equilibrium is indeterminate.

Region IV: $|\alpha \beta| \geq 1$ and $\left|\beta^{-1}-\gamma\right| \geq 1$

There is no equilibrium unless the exogenous crises, $\varepsilon_{\Psi t}$ and $\varepsilon_{\theta t}$, are perfectly correlated. In this case, monetary and fiscal policies are both active.

These results have important consequences for the optimal economic policy prescription. The optimal monetary policy rules that predominate in the literature, ranging from papers by Taylor to the more recent work by Woodford, explicitly or implicitly admit that the economy operates in region I. In this context, optimal rules are used in which the interest rate responds to variations in the output gap and inflation rate and, in the case of open economies, the interest-rate also responds to fluctuations in the exchange rate.

Also in the context of region I, optimal monetary rules are generally derived from the IS curve and the Phillips curve. More recently, most of these models start from a microeconomic foundations framework. Nonetheless, irrespective of the mode of derivation, the vast majority of the models in the international literature have something in common. The central bank's rule for setting the interest rate to keep inflation close to its target does not refer to fiscal variables. In other words, the interest rate does not respond to fiscal variables, 
whether taxes, primary deficit, or public deficit. As noted above, fiscal policy is passive because this is a Ricardian model. In this context, the debt and fiscal policy have no influence on the price level nor, therefore, on the inflation rate. For that reason, the use of a fiscal IS curve and the formulation of an interest-rate rule that responds to fiscal variables, makes no sense in an active monetary-policy and passive fiscal-policy environment. ${ }^{14}$

Moreover, taking account of the fact that a given economy operates in region II, in which the fiscal theory of the price level (FTPL) predominates, the application of an optimal monetary policy rule by controlling the interest rate, in the traditional way following Taylor, is questionable. It possibly makes more sense to use an optimal rule such as that proposed by Morais and Andrade (2004), which assumes the monetary authority pursues a flexible inflation targeting regime, which includes the possibility of a target for the debt/GDP ratio. In the proposed model, the public debt directly affects the risk premium and, consequently, the exchange rate. The authors include a target for the debt/GDP ratio based on the loss of monetary authority.

Common sense suggests that if the economy is in regions II, III, or IV, fiscal and monetary policies will need to be coordinated to be able to migrate to region I. Accordingly, the effect of the public debt on real and nominal variables of the economy cannot be neglected. It is therefore necessary to work with targets for reducing the debt/GDP ratio in a clear and transparent fashion.

Estimations are presented below for the coefficients $\gamma$ and $\alpha$ in equations (18) and (20), where $\gamma$ represents the reaction of direct taxes to variations in the public debt, and $\alpha$, which is derived from a simplified Taylor rule, represents the response of the interest rate to variations in inflation. The coefficient $\gamma$ is determined by estimating two equations as a system through the generalized method of moments, as shown in tables 14 and 15 . The coefficient $\alpha$ is also determined by an estimation of two equations as shown in table 16 and 17. As the Taylor rule used in the Leeper model is very simplified, a more common rule was used, in which the interest rate responds to expected inflation and the output gap.

The results shown in table 14 indicate that all variables, except the constant term, are statistically significant at the 5\% level. In this context, as the null hypothesis is rejected but there is a positive deterministic trend, fiscal policy is relatively unsustainable, because the problem of insolvency will eventually arise.

14 The term fiscal IS is used by Verdini (2003) as a result of the inclusion of a fiscal variable in the IS, in this case the primary surplus.
TABLE 14

Estimation using the generalized method of moments with the Bartlett kernel, Andrews bandwidth

$\left((B / Y)_{t}=a_{0}+a_{1}\right.$ Trend $+a_{2}(B / Y)_{t-1}+a_{4} *$ Dummy $\left.+u_{t}\right)$

\begin{tabular}{lcccr}
\hline Variables & Coefficients & $\begin{array}{c}\text { Standard } \\
\text { deviation }\end{array}$ & $\begin{array}{c}\text { Student } \\
\text { t-Statistic }\end{array}$ & P value \\
\hline Constant & 0.001 & 0.021 & 0.057 & 0.955 \\
Trend & 0.001 & $<0.001$ & 2.064 & 0.042 \\
$(\mathrm{~B} / \mathrm{Y})(-1)$ & 0.717 & 0.043 & 16.847 & $<0.001$ \\
Dummy & 0.146 & 0.031 & 4.636 & $<0.001$ \\
$\mathrm{R}^{2}$ & 0.968 & & Adjusted $\mathrm{R}^{2}$ & 0.966 \\
\hline
\end{tabular}

Source: prepared by the author.

Note: instruments $B / Y(-3,-4,-5,-6)$, I.D. $(-3,-4,-5,-6)$, c.

Trend: Tendency

Dummy: Dummy variable

$P$ value: Probability

TABLE 15

Estimation using the generalized method of moments with the Bartlett kernel, Andrews bandwidth

$\left(I D / Y_{t}=a_{3}+a_{4} *(B / Y)_{t-1}+\eta_{t}\right)$

\begin{tabular}{lcccr}
\hline Variables & Coefficients & $\begin{array}{c}\text { Standard } \\
\text { deviation }\end{array}$ & $\begin{array}{c}\text { Student } \\
\text { t-Statistic }\end{array}$ & P value \\
\hline Constant & 0.006 & $<0.001$ & 27.282 & $<0.001$ \\
$(\mathrm{~B} / \mathrm{Y})(-1)$ & 0.005 & $<0.001$ & 10.035 & $<0.001$ \\
$\mathrm{R}^{2}$ & 0.386 & & Adjusted $\mathrm{R}^{2}$ & 0.373 \\
\hline
\end{tabular}

Source: prepared by the author.

Note: Instruments $B / Y(-3,-4,-5,-6), I D / Y(-3,-4,-5,-6)$, c.

P value: Probability

TABLE 16

Estimation using the generalized method of moments with the Bartlett kernel, fixed bandwidth

$\left(y_{t}=a_{1}+a_{2} y_{t-1}+a_{3} r_{t-1}+a_{4} e_{t-1}+a_{5} *\right.$ Dummy $\left.+\eta_{t}\right)$

\begin{tabular}{lcccr}
\hline Variables & Coefficients & $\begin{array}{c}\text { Standard } \\
\text { deviation }\end{array}$ & $\begin{array}{c}\text { Student } \\
\text { t-Statistic }\end{array}$ & P value \\
\hline Constant & 0.8555 & 0.096 & 8.947 & $<0.001$ \\
Output gap & 0.331 & 0.077 & 4.312 & $<0.001$ \\
Interest-r & -0.236 & 0.031 & -7.612 & $<0.001$ \\
Exchange rate-r & 0.111 & 0.028 & 3.971 & $<0.001$ \\
Dummy & 0.274 & 0.036 & 7.659 & $<0.001$ \\
$\mathrm{R}^{2}$ & 0.505 & & Adjusted $\mathrm{R}^{2}$ & 0.460 \\
\hline
\end{tabular}

Source: prepared by the author.

Note: Instruments $R(-2,-3,-4,-5,-6)$, ipca $(-2,-3,-4,-5,-6), B / Y(-2$, $-3,-4,-5,-6), c$.

Dummy: Dummy variable

P value: Probability 
TABLE 17

Estimation using the generalized method of moments with the Bartlett kernel, Andrews bandwidth

$\left(R_{t}=a_{6}+a_{7} * E_{t}\left(\pi_{t+1}\right)+a_{8} * y_{t}+a_{9} * R_{t-1}+\eta_{t}\right)$

\begin{tabular}{lcccr}
\hline Variables & Coefficients & $\begin{array}{c}\text { Standard } \\
\text { deviation }\end{array}$ & $\begin{array}{c}\text { Student } \\
\text { t-Statistic }\end{array}$ & P value \\
\hline Constant & -0.315 & 0.054 & -5.835 & $<0.001$ \\
$E_{t}\left(\pi_{t+1}\right)$ & 0.149 & 0.038 & 3.940 & $<0.001$ \\
Output gap & 0.177 & 0.033 & 5.398 & $<0.001$ \\
SELIC (-1) & 0.872 & 0.026 & 34.070 & $<0.001$ \\
$\mathrm{R}^{2}$ & 0.789 & & Adjusted $\mathrm{R}^{2}$ & 0.775 \\
\hline
\end{tabular}

Source: prepared by the author.

Note: Instruments $R(-2,-3,-4,-5,-6)$, ipca $(-2,-3,-4,-5,-6), B / Y(-2$, $-3,-4,-5,-6), \mathrm{c}$.

SELIC: Special settlement and custody system rate $E_{t}\left(\pi_{t+1}\right)=$ inflation expectations in period $t$ for the period $t+1$. $P$ value: Probability

The value of the J-statistic at 0.20 , with a $\mathrm{P}$ value of 0.97 , does not provide evidence to reject the model specification.

The results shown in table 15 indicate that all variables are statistically significant at the $1 \%$ level. For every $1 \%$ increase in the debt/GDP ratio, there is a $0.005 \%$ increase in the ratio of direct taxes to GDP. That value represents the coefficient $\gamma$ in the Leeper (1991) model, which shows the reaction of direct taxes to variations in the public debt.

The results shown in table 16 correspond to the estimation of an IS curve in which all variables are statistically significant at the $1 \%$ level. All coefficients have the expected sign.

The value of the $\mathrm{J}$-statistic at 0.25 , with a $\mathrm{P}$ value of 0.90 , does not provide evidence to reject the model specification.

The results shown in table 17 represent the estimation of the Taylor rule in which all variables are statistically significant at the $1 \%$ level. All coefficients have the expected sign. It is assumed that $E_{t}\left(\pi_{t+1}\right)=\pi_{t+1}$. For every $1 \%$ increase in the expected value of inflation, the SELIC rises by $0.149 \%$. That value represents the coefficient $\alpha$ of the Leeper (1991) model, which shows how the interest rate responds to to variations in inflation.

Based the foregoing results, where the coefficient $\alpha=0.149$ (see table 17), and the coefficient $\gamma=0.005$ (see table 15), and bearing in mind that $\beta=0.98$, a unique equilibrium is attained in region II, such that $|\alpha \beta|<1$ and $\left|\beta^{-1}-\gamma\right| \geq 1$. It should be noted that $|\alpha \beta|=|0.149 * 0.98|<1$ and that $\left|\beta^{-1}-\gamma\right|=|1 / 0.98-0.005|>1$. The same value of $\beta=0.98$ was used estimated by Lima and Issler (2003) and followed by Moreira, Souza and Almeida (2007a and 2007b). These results indicate that the economy is in region II.

Although the output gap is included in equation 20, following Moreira, Souza and Almeida (2007b), the Taylor rule was also tested without the gap, as per the Leeper (1991) model. In this case the result is maintained, in other words, the economy remains in region II. ${ }^{15}$ To guarantee the robustness of the results, an alternative measure for measuring the output gap was also used. Following the work of Cusinato, Minella and Júnior (2010) on measures of the output gap in Brazil, it was decided to use the quadratic trend extraction method. The results obtained are similar to those shown in tables 16 and 17, which use the output gap estimated with the Hodrick-Prescott filter. Once again, the economy is in region II.

The results also are maintained with respect to the monthly series of the Institute of Applied Economic Research (IPEA) for the period from July 2001 to December 2009. The real interest rate was calculated as the difference between the cumulative SELIC rate for the next 12 months (annual percentage) and the average inflation expectation, according to the Extended National Consumer Price Index. (IPCA) - cumulative rate for the next 12 months (annual percentage). The output gap was calculated on the basis of the (general) industrial production index using the Hodrick-Prescott filter. The same monthly variables were used as in the models in tables 14 and 15, and 16 and 17. The estimations gave the same result, namely that in the flexible exchange rate and inflation-targeting period, the economy is operating in region II.

\footnotetext{
15 Based on the Leeper (1991) model, Moreira, Souza and Almeida (2007a) show that fiscal and monetary policies are both passive in the period 1999-2004. Almeida, Moreira and Souza (2008) show that the fiscal deficit affects the inflation rate indirectly through the output gap, based on the stimation of an IS curve and the Phillips curve for the period January 1996 to January 2007.
} 


\section{IV}

\section{Final comments}

The results presented in subsection 7, based on the Leeper model, show that the Brazilian economy is in a situation of fiscal dominance. This is consistent with the results reported in the earlier subsections. It should be noted that all the fiscal sustainability tests based on Buiter and Patel (1992) showed that Brazil's fiscal situation in the period analysed is worrying to say the least. The fiscal policy transmission channels can be defined schematically, as shown in tables 18 and 19.

Table 18 shows fiscal policy transmission mechanisms that operate through the money supply. It shows the effects of variations in the public debt on the primary surplus, monetary base, interest rate, investment, and the output gap.

The results described in section III show that the primary surplus reacts positively to variations in the public debt. Nonetheless, the fact that the coefficient of the debt/GDP ratio is positive and statistically significant does not mean it is large enough to guarantee fiscal sustainability. In that case, according to Leeper (1991), the fiscal authority refuses to make a substantial adjustment in direct taxation, thus preventing the repercussion on the deficit from being fully financed by future taxes. As noted above, the federal government's primary surplus is recorded in the National Treasury single account, which forms part of the central bank's non-monetary liabilities. As the variation in the monetary base corresponds to the difference between the variation in central bank assets and the variation in its non-monetary liability, if there is an increase in the primary surplus (and hence in the National Treasury single account recorded in the nonmonetary liability), with everything else held constant, there will be a reduction in the monetary base. In that context, successive increases in the primary surplus will lead to a contraction in the monetary base, ceteris paribus, and consequently a reduction in means of payment. This institutional structure shows the existence of a direct channel for transmitting fiscal policy to monetary policy.

As increases in the primary surplus are known to cause a reduction in the monetary base, once again ceteris paribus, the interest rate is likely to rise. The results show that the public debt has a positive effect on the nominal SELIC interest rate, and that increases in the public debt cause increases in the primary surplus, which translate into interest-rate hikes. Assuming that higher

$$
\begin{aligned}
& \uparrow(B / Y) \Rightarrow \uparrow(S P / Y) \Rightarrow \uparrow(\text { Single Treasury Account }) \Rightarrow \uparrow(\text { Nonmonetary liability }) \Rightarrow \\
& \downarrow(\text { Monetary base }) \Rightarrow \downarrow(M) \Rightarrow \uparrow R \Rightarrow \downarrow(I) \Rightarrow \downarrow(y) \uparrow(\bar{B} / Y) \Rightarrow \uparrow(S P / Y) \\
& \text {.....vicious circle }
\end{aligned}
$$

Source: prepared by the author.

SP: Primary surplus.

$\uparrow(B / Y) \Rightarrow \uparrow($ demand for money $) \Rightarrow \uparrow R \Rightarrow \downarrow(I) \Rightarrow \downarrow(y) \uparrow(\bar{B} / Y) \Rightarrow$ (demand for money) vicious circle

Source: prepared by the author. 
nominal interest rates are accompanied by a higher real interest rates, then increases in the public debt can also be expected to cause lower levels of investment and output. The estimations confirm this negative relation between public debt and levels of investment and the output gap. Having said that, lower levels of output, for a given debt level, result in a higher debt/GDP ratio. This feedback process can generate an undesirable vicious circle.

Similarly to table 18 , table 19 shows how fiscal policy is propagated from variations in the debt/GDP ratio, although in this case through the demand for money. The results show that increases in the debt/GDP ratio increase the demand for money, which means economic agents consider part of the public debt as net wealth, and, consequently, the model is non-Ricardian. A higher demand for money, given the supply of money, suggests a rise in the interest rate.

The results also suggest that increases in the debt/GDP ratio push up the interest rate. The empirical tests show that an interest-rate hike causes reductions in the level of investment and the output gap (see table 19), which can also produce the same undesirable vicious circle.

ANNEX

TABLE A. 1

Unit root test

\begin{tabular}{|c|c|c|c|c|c|c|}
\hline \multirow{2}{*}{ Variables } & \multicolumn{3}{|c|}{ ADF - AIC modified } & \multicolumn{3}{|c|}{ ADF - SIC modified } \\
\hline & $\begin{array}{l}\text { Critical } \\
\text { value 5\% }\end{array}$ & $\begin{array}{c}\text { Student } \\
\text { t-statistic }\end{array}$ & Value $\mathrm{P}$ & $\begin{array}{c}\text { Critical } \\
\text { value 5\% }\end{array}$ & $\begin{array}{l}\text { Student } \\
\text { t-statistic }\end{array}$ & Value $\mathrm{P}$ \\
\hline $\mathrm{L}(\mathrm{m})$ & -2.927 & -1.701 & 0.424 & -2.921 & -2.196 & 0.210 \\
\hline $\mathrm{L}(\mathrm{R})$ & -2.919 & -2.506 & 0.120 & -2.919 & -2.506 & 0.120 \\
\hline $\mathrm{L}(\mathrm{b})$ & -3.502 & -2.145 & 0.509 & -3.495 & -2.518 & 0.319 \\
\hline L(I/Y-1) & -2.924 & -0.723 & 0.831 & -2.924 & -0.723 & 0.831 \\
\hline $\mathrm{L}(\mathrm{B} / \mathrm{Y}-1)$ & -1.949 & -0.916 & 0.314 & -1.947 & -0.506 & 0.821 \\
\hline $\mathrm{L}(\mathrm{SP} / \mathrm{Y})$ & -2.919 & -0.929 & 0.771 & -2.919 & -0.929 & 0.771 \\
\hline
\end{tabular}

Source: prepared by the author.

ADF: Augmented Dickey-Fuller test.

AIC: Akaike information criterion.

SIC: Schwarz criterion.

L: logarithm.

SP: Primary surplus.

$P$ value: Probability. 
TABLE A. 2

Johansen co-integration test: $L(I / Y-1)=f[L(B / Y-1)]$

\begin{tabular}{lrrrr}
\hline $\begin{array}{l}\text { Hypothesis: number } \\
\text { of co-integration } \\
\text { equations }\end{array}$ & Eigenvalue & $\begin{array}{c}\text { Trace } \\
\text { tests }\end{array}$ & $\begin{array}{c}\text { Critical } \\
\text { value 5\% }\end{array}$ & P value \\
\hline $\begin{array}{l}\text { None } \\
\text { At least 1 }\end{array}$ & 0.333 & 29.388 & 20.262 & 0.002 \\
\hline
\end{tabular}

Source: prepared by the author.

Note: the trace test indicates a co-integration equation at the 5\% level.

a Indicates rejection of the null hypothesis at the 5\% level.

$P$ value: Probability.

TABLE A. 3

\section{Johansen co-integration test: $\mathrm{L}(\mathrm{I} / \mathrm{Y}-1)=\mathrm{F}[\mathrm{L}(\mathrm{B} / \mathrm{Y}-1)]$}

\begin{tabular}{lrrrr}
\hline $\begin{array}{l}\text { Hypothesis: number } \\
\text { of co-integration } \\
\text { equations }\end{array}$ & Eigenvalue $\begin{array}{c}\text { Maximum } \\
\text { Eigenvalue } \\
\text { statistic }\end{array}$ & $\begin{array}{c}\text { Critical } \\
\text { value 5\% }\end{array}$ & P value \\
\hline None $^{\text {a }}$ & 0.333 & 20.662 & 15.892 & 0.008 \\
At least 1 & 0.157 & 8.726 & 9.164 & 0.060 \\
\hline
\end{tabular}

Source: prepared by the author.

Note: The maximum eigenvalue test indicates a co-integration equation at the $5 \%$ level.

a Indicates rejection of the null hypothesis at the 5\% level.

$P$ value: Probability.

TABLE A 4

Johansen co-integration test: $L(M / Y)=F[L(R), L(B / Y)]$

\begin{tabular}{lcrrr}
\hline $\begin{array}{l}\text { Hypothesis: number } \\
\text { of co-integration } \\
\text { equations }\end{array}$ & Eigenvalue & $\begin{array}{c}\text { Trace } \\
\text { test }\end{array}$ & $\begin{array}{c}\text { Critical } \\
\text { value 5\% }\end{array}$ & P value \\
\hline None $^{\mathrm{a}}$ & 0.421 & 39.705 & 35.193 & 0.015 \\
At least 1 & 0.207 & 12.347 & 20.262 & 0.418 \\
At least 2 & 0.014 & 0.726 & 9.164 & 0.981 \\
\hline
\end{tabular}

Source: prepared by the author.

Note: The trace test indicates a co-integration equation at the $5 \%$ level.

a Indicates rejection of the null hypothesis at the $5 \%$ level. $P$ value: Probability.
TABLE A.5

$$
\begin{aligned}
& \text { Johansen co-integration test: } \\
& L(M / Y)=f[L(R), L(B / Y)]
\end{aligned}
$$

\begin{tabular}{lrrrr}
\hline $\begin{array}{l}\text { Hypothesis: number } \\
\text { of co-integration } \\
\text { equations }\end{array}$ & Eigenvalue & $\begin{array}{c}\text { Maximum } \\
\text { Eigenvalue } \\
\text { statistic }\end{array}$ & $\begin{array}{c}\text { Critical } \\
\text { value 5\% }\end{array}$ & P value \\
\hline None $^{\text {a }}$ & 0.421 & 27.358 & 22.299 & 0.009 \\
At least 1 & 0.207 & 11.622 & 15.892 & 0.209 \\
At least 2 & 0.014 & 0.726 & 9.164 & 0.981 \\
\hline
\end{tabular}

Source: prepared by the author.

Note: The maximum eigenvalue test indicates a co-integration equation at the $5 \%$ level.

a Indicates rejection of the null hypothesis at the $5 \%$ level.

$P$ value: Probability.

\section{TABLE A.6

$$
\begin{aligned}
& \text { Johansen co-integration test: } \\
& L(S P / Y)=f[L(B / Y)]
\end{aligned}
$$

Hypothesis: number of co-integration Eigenvalue Trace test $\begin{gathered}\text { Critical } \\ \text { value } 5 \%\end{gathered}$ P value equations

\begin{tabular}{lrrrr}
\hline None $^{\mathrm{a}}$ & 0.532 & 47.908 & 20.262 & $<0.001$ \\
At least 1 & 0.150 & 8.434 & 9.164 & 0.070
\end{tabular}

Source: prepared by the author.

Note: The trace test indicates one co-integration equation at the $5 \%$ level.

a Indicates rejection of the null hypothesis at the 5\% level.

$P$ value: Probability.

TABLE A.7

$$
\begin{aligned}
& \text { Johansen co-integration test: } \\
& L(S P / Y)=f[L(B / Y)]
\end{aligned}
$$

\begin{tabular}{lrrrr}
\hline $\begin{array}{l}\text { Hypothesis: number } \\
\text { of co-integration } \\
\text { equations }\end{array}$ & Eigenvalue & $\begin{array}{c}\text { Maximum } \\
\text { Eigenvalue } \\
\text { statistic }\end{array}$ & $\begin{array}{c}\text { Critical } \\
\text { value 5\% }\end{array}$ & P value \\
\hline None $^{\mathrm{a}}$ & 0.532 & 39.474 & 15.892 & $<0.001$ \\
At least 1 & 0.150 & 8.435 & 9.164 & 0.070 \\
\hline
\end{tabular}

Source: prepared by the author.

Note: The maximum eigenvalue test indicates a co-integration equation at the $5 \%$ level.

a Indicates rejection of the null hypothesis at the $5 \%$ level.

$P$ value: Probability. 
TABLE A.8

\section{Description of variables}

\begin{tabular}{|c|c|c|}
\hline Variables & Unit of measurement & Source \\
\hline Means of payment - end period (M) & Millions of reais & IPEA \\
\hline GDP- market prices (Y) & Millions of reais & IPEA \\
\hline Interest rate - over/SELIC $(R)$ & Percentages & IPEA \\
\hline Gross fixed capital formation - $(I)$ & Millions of reais & IPEA \\
\hline Implicit GDP deflator $(P)$ & Index number & IPEA \\
\hline Nominal exchange rate - reais/dollar-commercial -buying - average $(E)$ & Percentages & IPEA \\
\hline Real effective exchange rate - INPC - exports $(e)$ & Percentages & IPEA \\
\hline $\begin{array}{l}\text { Primary surplus (NFPS) -Federal government and central bank -primary - with } \\
\text { exchange-rate devaluation }(S P)\end{array}$ & Millions of reais & IPEA \\
\hline Inflation rate - IPCA $(\pi)$ & Percentages & IPEA \\
\hline Direct taxes = individual and corporate income taxes + rural property tax (ID) & Millions of reais & IPEA \\
\hline Public debt, federal public bonds and open market operations $(B)$ & Millions of reais & BACEN \\
\hline Average inflation expectations - IPCA - cumulative rate for the next 12 months $E_{t}\left(\pi_{t+1}\right)$ & Percentages & IPEA \\
\hline Industrial production - general industry & $\begin{array}{l}\text { Quantum - seasonally adjusted index } \\
\text { (average } 2002=100 \text { ) }\end{array}$ & IPEA \\
\hline
\end{tabular}

Source: prepared by the author.

GDP: Gross domestic product

ID: Direct taxes

IPEA: Institute of Applied Economic Research

BACEN: Central Bank of Brazil

IPCA: Extended National Consumer Price Index

INPC: National Consumer Price Index

NFSP: Public sector financing needs

Quantum: Quantity index

over/SELIC rate: Daily indicator of the interest rate, corresponding to the average adjusted daily rate of financing of federal government bonds, calculated in the Special Settlement and Custody System (SELIC) and published by the Central Bank of Brazil. This is the basic interest rate in Brazil.

(Original: Portuguese)

\section{Bibliography}

Almeida, Ch., T. Moreira and G. Souza (2008), "Optimal monetary rules in a context of fiscal disequilibrium: evidence from Brazil - 1996:I to 2007:I", Economia e desenvolvimento (Recife), Recife, Universidade Federal de Pernambuco.

Araujo, J.T. and M.A.C. Martins (1999), "Economic growth with finite lifetimes", Economics Letters, vol. 62, No. 3, Amsterdam, Elsevier.

Barro, R.J. (1974), “Are government bonds net wealth?", Journal of Political Economy, vol. 82, No. 6, Chicago, University of Chicago Press.

Blanchard, O. (2004), "Fiscal dominance and inflation targeting: lessons from Brazil", NBER Working Paper, No. 10389, Cambridge, Massachusetts, March.
Bohn, H. (1998), "The behavior of U.S. public debt and deficits", The Quarterly Journal of Economics, vol. 113, No. 3, Cambridge, Massachusetts, The MIT Press.

Buiter, W. and R. Patel (1992), "Debt, deficits and inflation: an application to the public finances of India", Journal of Public Economics, vol. 47, No. 2, Amsterdam, Elsevier.

Cusinato, R., A. Minella and S. Júnior (2010), "Hiato do produto e PIB no Brasil: uma análise de dados em tempo real", Trabalhos para discussão, No. 203, Brasilia, Central Bank of Brazil, April.

Fisher, I. (1930), The Theory of Interest, New York, Macmillan.

Hodrick, R.J. and E.C. Prescott (1997), "Postwar U.S. business cycles: an empirical investigation", Journal of Money, Credit 
and Banking, vol. 29, No. 1, New York, Blackwell Publishing, February.

Hsiao, C. (1997a), "Statistical properties of the two-stage least squares estimator under co-integration", The Review of Economic Studies, vol. 64, No. 3, New York, Blackwell Publishing.

(1997b), "Co-integration and dynamic simultaneous equations models", Econometrica, vol. 65, No. 3, New York, The Econometric Society.

Johnston, J. and J. DiNardo (1997), Econometric Methods, New York, McGraw-Hill.

Kneebone, R.D. (1989), "On macro-economic instability under a monetarist policy rule in a federal economy", The Canadian Journal of Economics, vol. 22, No. 3, Quebec, Canadian Economics Association, August.

Leeper, E.M. (1991), "Equilibria under 'active' and 'passive' monetary and fiscal policies", Journal of Monetary Economics, vol. 27, No. 1, Amsterdam, Elsevier.

Lima, A.M.C. and J.V. Issler (2003), "A hipótese das expectativas na estrutura a termo de juros no Brasil: uma aplicação de modelos de valor presente", Revista brasileira de economia, vol. 57, No. 4, Rio de Janeiro, Getulio Vargas Foundation, October/December.

Loyo, E. (1999), "Tight money paradox on the loose: a fiscalist hyperinflation”, JFK School of Government, Harvard University, June, unpublished.

Luporini, V. (2006), "Conceitos de sustentabilidade fiscal", Textos para discussão, No. 189, Universidade Federal Fluminense, May [online] http:/www.uff.br/econ

Martins, M.A.C. (1980), "A nominal theory of the nominal rate of interest and the price level", The Journal of Political Economy, vol. 88, No. 1, Chicago, University of Chicago Press, February.

Mendonça, M.J., L.A. Medrano and A. Sachsida (2009), "Avaliando os efeitos da política fiscal no Brasil: resultados de um procedimento de identificação agnóstica", Textos de discusión, No. 1377, Brasilia, Institute of Applied Economic Research (IPEA).

Morais, J.F.M and J.P. de Andrade (2004), "Como a dívida pública afeta a política monetária ótima?”, Finanças Públicas - IX Prêmio Tesouro Nacional, Brasilia, Escola de Administração Fazendária (ESAF).

Moreira, T.B.S. and G. da S. Souza (2009), "A nominal theory of the nominal rate of interest and the price level: some empirical evidence", Economics Bulletin, vol. 29, No. 4.
Moreira, T.B.S., G. da S. Souza and Ch.L. Almeida (2007a), "Política fiscal e monetária: ativa ou passiva? Uma análise empírica e suas implicações sobre as regras ótimas de política monetária", Cadernos de finanças públicas, Brasilia, Escola de Administração Fazendária (ESAF).

(2007b), "The fiscal theory of the price level and the interaction of monetary and fiscal policies: the Brazilian case", Brazilian Review of Econometrics, vol. 27, No. 1, Rio de Janeiro, Sociedade Brasileira de Econometria, May.

Phillips, P.C.B. (1988), "Regression theory for near-integrated time series", Econometrica, vol. 56, No. 5, New York, The Econometric Society, September.

Phillips, P.C.B. and P. Perron (1988), "Testing for a unit roots in time series regression", Biometrika, vol. 75, No. 2, Oxford University Press

Sala, L. (2004), "The fiscal theory of the price level: identifying restrictions and empirical evidence", Working Paper, No. 257, Innocenzo Gasparini Institute for Economic Research (IGIER), Milan, April

Sargent, T.J. and N. Wallace (1981), "Some unpleasant monetarist arithmetic", Federal Reserve Bank of Minneapolis Quarterly Review, vol. 5, No. 3, Minneapolis, Federal Reserve Bank of Minneapolis.

Scarth, W.M. (1996), Macroeconomics: An Introduction to Advanced Methods, Canada, Harcourt Brace \& Company.

Souza, G., T.B.S. Moreira and J.R. Albuquerque (2007), "Intertemporal solvency and public debt: evidence from Brazil - 1995-2004", Planejamento e políticas públicas, No. 30, Brasilia, Institute of Applied Economic Research (IPEA), June/December.

Taylor, J.B. (1993), "Discretion versus policy rules in practice", Carnegie-Rochester Conferences Series on Public Policy, vol. 39, No. 1, Amsterdam, Elsevier, December.

Verdini, M. (2003), "Regras monetárias e restrição fiscal: uma análise da política de metas para a inflação no Brasil”, unpublished.

Wilcox, D. (1989), "The sustainability of government deficits: implications of the present-value borrowing constraint", Journal of Money, Credit and Banking, vol. 21, No. 3, New York, Blackwell Publishing, August.

Woodford, M. (2003), Interest and Prices, Princeton, Princeton University Press.

(1995), "Price level determinacy without control of a monetary aggregate", NBER Working Paper, No. 5204, Cambridge, Massachusetts, National Bureau of Economic Research. 